\title{
Socio-Economic Condition of Urban Street Food Vendors
}

\section{OPEN ACCESS}

Manuscript ID:

ECO-2020-08033193

Volume: 8

Issue: 3

Month: June

Year: 2020

P-ISSN: 2319-961X

E-ISSN: 2582-0192

Received: 30.04 .2020

Accepted: 21.05.2020

Published: 01.06.2020

Citation:

Tigari, Harish and Shalini,

S. "Socio-Economic

Condition of Urban Street

Food Vendors." Shanlax

International Journal of

Economics, vol. 8, no. 3, 2020, pp. 67-74.

DOI:

https://doi.org/10.34293/

economics.v8i3.3193

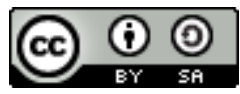

This work is licensed under a Creative Commons Attribution-ShareAlike 4.0 International License

\section{Harish Tigari}

Assistant Professor and Co-ordinator, Davan PG Studies, Davangere, Karnataka, India

https://orcid.org/0000-0002-3770-6045

S. Shalini

Davan PG Studies, Davangere, Karnataka, India

Abstract

The street food sector plays an important role in urban areas of many developing countries. Street food represents a significant part of urban food consumption for millions of low and middle-income consumers in urban areas daily. Street foods may be the least expensive and most accessible means of obtaining a nutritionally balanced meal outside the home for many low-income people. In Davanagere city most of the vendors are poorly educated, untrained in food hygienic food, and most of the foods are not well protected from flies; street food is relatively cheap. You can get to try a wide selection of different foods in one place. Street food stands are a source of income for many families. Some street food vendors are facing problems like those that don't have their van or shop. They have to pay a limited amount of money for this. And they earn only a little profit.

Keywords: Street food, Self-employment, Capital investment, Women Entrepreneurs.

\section{Introduction}

Street food-The The street food and agriculture organization define street food as ready to eat food and beverages prepared or sold by vendors and hawkers, especially in streets and similar public places. According to the study conducted by food and agriculture organization in the year 2007, 2.5 billion people eat street food daily - a significant part of urban food consumption for millions of low and middle-income consumers in urban areas daily. And there are plenty of types of food sold on the street, and different places bring different flavors of street foods. With the changes in lifestyle through people are aware of the impacts after consuming street food; still, they prefer because of the convenience and price. Street vendors sell different kinds of goods such as clothes, hosiery, leather, molded plastic goods, and different kinds of household goods, which are manufactured in small scale or home-based industries. Street vendors are among the most vulnerable workers group in the unorganized sector in any developing and underdeveloped states their income levels are very low and uncertain. The term 'Street vendors' refers to those who are unable to get a regular job in the remunerative of the formal sector due to lack of a low level of education and skills. However, street vending is an important activity related to urban areas. The terms street vendors describe them are based on time or place where they work. Usually, street food vendors are starting their own business with low initial investment even they do not have proper materials, and they have low-cost seating facilities, which are sometimes rudimentary. They provide a variety of goods at lower prices; vendors' stalls are usually located outdoors or under a roof, which is easily accessible from the street. One of the common sights in urban centers in the country today is the street food stall, through an age-old business street food has gained popularity in the recent years due to various reasons which include rapid urbanization, increased rural 
to urban migration and the need for self-employment due to lack of other jobs/employment opportunities, the need to augment the family income, the increasing cost of meals in traditional food services facilities and the changes in the lifestyle of the people such as the increased need to eat outside the homes. They occupy the lowest position in the long chain of hierarchy, i.e., their economic conditions are as poor as that of a coolie. And long hours of work involving continuous strain; they work from very early hours of the morning until sunset, sometimes beyond that, they work in unsafe and unhealthy conditions. Although street vending has been seen as an option for the poor: street food vendors preferred the place with the busy area at an overcrowded area like a bustard, collages, railway station, etc. the most of the street food vendors are poor in the knowledge and untrained in the street food hygiene the most of the street food vendors food are not well protected from his, like a food storage post-cooking food it should cause health problem vendors usually see the overcrowded places, because of they earn money. Some health problems in the street foods like food safety poor in water supplies, some lack of infrastructure, uncleanness, and street food vendors do not have that much of the knowledge about food safety measures. The street food vending as a business, it provides a means of income to many unemployed in the urban areas. The informal food sector plays a vital role in the urban area of many developing countries. Today's people eat more of street foods roadside stall. The hotel is some restaurant's services are do not giving the food for less cost, so that's why people prefer street foods. The consumers prefer tasty, and quality meals for their family members and street foods served should go very quickly. Several of the street foods are taking out, snacks with various local flavors, and consumers should be enjoying it. Street vendors have poverty is the main cause to do the street vending poor business people are always doing their business in an unorganized sector, both rural and urban areas to the economic development they have a little amount to do their business, and they have lees income.

\section{Review of literature}

(Mr. Jannie bough-Petersen, et al. 2010) conducted the study on the topic 'Street food in
Kolkata'- A hygienic perspective. In this study, it focused on the hygienic of street food vendors and using the various hygienic theory from the processing step into the consumer vendors to get their commodities from the quality of them.

(Mr. Etzold, Benjamin, et al. 2013) conducted the study on the topic 'Street food vending in Dhaka: the livelihood of the urban poor and the encroachment of public space" analyzed street food vendors and consumers all over Dhaka shows how street food is very important in place of Dhaka not only in terms of the urban food security and the provision and labor force but also it provides the livelihood opportunities for urban unemployed people.

(Mr. Tavonganjaya 2014) conducted a study on the topic "operations of street food vendors and their impact on sustainable urban life in high-density suburbs of 'Harare' in 'Zimbabwe' observed that street food vending is playing a vital role in the socio-economic, in Harare the street food vending is far from being a delay to progress and sustainable development the street foods vending is reduced the unemployment.

(Mr. Wai yee Lin, et al. 2014) both are conducted the study on the topic "consumer attitude on vendors practices and safety aspects street food in Yangon'. In this study, the consumer-preferred more because of their time saved and street foods how much effective utilization of street food.

(Mr sezgin, Aybuke \& Senlier Nevin 2016) conducted a study on the topic "Street food consumption in terms of the food safety and health stated that nowadays the more of the people eating street foods in every day the street foods and some beverage should be sold in the public place at the busy area at an overcrowded area like a bus stand, schools, colleges, railways stations, etc. in this study shows the more of the countries policies there is no lawful arrangement for the food safety measures.

(Mr. Bhatt Bhaskar, et al. 2018) they conducted a study on the topic "A study of street vending activities in the southeast zone of Surat. They said many people are migrating from rural to urban areas in search of jobs. If not possible to get a job, they do their own business at micro-level and street food vendors using public places and busy areas and overcrowded areas to sell the street food. 
(M.S.S.K Lakshmi Baal, et. al 2018) conducted the study on the topic 'study of hygienic practices of street food vendors India and determination of critical control point's street food'. They stated that food contamination in the Allahabad city. Water quality and food safety measures and some foods are not well protected from the flies post-cooking. It should be injuries to human health and hygienic during the food prepared.

\section{Objectives}

- To study the socio-economic condition of street food vendors.

- To analyze the problems of street food vendors.

\section{The Methodology of the Study}

The methodology is the systematic, theoretical analysis of the methods applied to a field of study. It comprises the theoretical analysis of the body of methods and principles associated with the branch of knowledge. The methodology has the following two methods

Primary data: primary data consist of face to face interaction. Searching something. Creative information about particular research or project. The primary data was obtained through the customer survey, by personal interviews and questionnaire method at Davangere region.

Secondary data: Secondary data is data which is consists of internet information, newspapers, articles, etc.

For consider research, both primary and secondary data are used regarding on, and the research is completely focused on street food vendors and derived the data by interaction and discussions, their personal and individual information. Primary data have been collected 30 respondents from Davanagere city through the questionnaire. Secondary data have been collected internet, articles as well as through some websites, etc

\section{Scope of the Study}

This study is based on the socio-economic condition of street food vendors, their service, and food safety measures. Street food vendor's hygienic perspective and customer health. I have taken 30 respondents in a certain area. The study is restricted to the Davanagere city.

\section{Need for the Study}

Today we observe that many people prefer street food rather than going to restaurants, and the street food business is growing rapidly. Because people will like more street food, so this is a greater chance of understanding the street food vendors' income and expenditure pattern and food safety measures.

\section{Limitations of the Study}

- It was time-consuming as I had to move from one place to another.

- The study is restricted to 30 respondents.

- The interpretation should be based on the assumption that the respondents have given the correct information

- Some of the respondents were not co-operative.

- Lack of response.

\section{Data Analysis and Interpretation}

Table 1: Demographic Profile of Street Vendors

\begin{tabular}{|l|c|c|l|c|c|}
\hline \multicolumn{1}{|c|}{ Gender } & $\mathbf{F q}$ & $\mathbf{\%}$ & Marital status & $\mathbf{F q}$ & $\mathbf{\%}$ \\
\hline Male & 23 & 76.66 & Married & 26 & 86.66 \\
\hline Female & 07 & 23.33 & Unmarried & 04 & 13.33 \\
\hline Total & $\mathbf{3 0}$ & $\mathbf{1 0 0}$ & Total & $\mathbf{3 0}$ & $\mathbf{1 0 0}$ \\
\hline Education & $\mathbf{F q}$ & $\mathbf{\%}$ & Age & $\mathbf{F q}$ & $\mathbf{\%}$ \\
\hline Illiterates & 06 & 20.00 & $15-20$ & 03 & 10.00 \\
\hline Primary & 09 & 30.00 & $20-30$ & 06 & 20.00 \\
\hline Secondary & 13 & 43.33 & $30-40$ & 15 & 20.00 \\
\hline UG \& above & 03 & 06.66 & 40 above & 06 & 20.00 \\
\hline Total & $\mathbf{3 0}$ & $\mathbf{1 0 0}$ & Total & $\mathbf{3 0}$ & $\mathbf{1 0 0}$ \\
\hline
\end{tabular}

Source: Field survey 
Gender: From the above total, it shows that $76.66 \%$ of respondents were male, while the remaining $23.33 \%$ of respondents were female. We can observe that males are more, females are very less in this category. Males are willing to do this street food business.

Age: From the above table it shows that 10\% respondents belong to the age group between 1520 year, $20 \%$ respondents belong to the age group between $20-30$ and $50 \%$ respondents belong to the age group 30-40 and remaining 20\% respondents belong to the age group of above 40 years.
Education: From the above table, 20\% of respondents are Illiterates, $30 \%$ of respondents are primary, and $43.33 \%$ of respondents are secondary, and the remaining $6.66 \%$ of respondents are complete their degree. These people are not getting any job because of this reason they are doing street food business.

Marital Status: From the above table shows that the marital status of the respondents, $86.66 \%$ of respondents were married. In comparison, the remaining $13.33 \%$ of respondents were unmarried. We can observe that married people are more in this category.

Table 2: Firm Age, Investment, Savings and Income

\begin{tabular}{|c|c|c|c|c|c|}
\hline Monthly income & $\mathbf{F q}$ & $\%$ & Age of firm & $\mathbf{F q}$ & $\%$ \\
\hline Below-5000 & 02 & 06.66 & Below 1 year & 07 & 23.33 \\
\hline $5000-10000$ & 09 & 30.00 & $1-5$ year & 14 & 46.66 \\
\hline $10000-20000$ & 12 & 40.00 & 5-10 years & 08 & 26.66 \\
\hline Above 20000 & 07 & 23.33 & Above 10 years & 01 & 03.33 \\
\hline Total & 30 & 100 & Total & 30 & 100 \\
\hline Monthly expenses & $\mathbf{F q}$ & $\%$ & Initial Invest & $\mathbf{F q}$ & $\%$ \\
\hline $5000-7000$ & 09 & 30.00 & $1000-10000$ & 03 & 10 \\
\hline $7000-10000$ & 08 & 26.66 & $10000-20000$ & 15 & 50 \\
\hline 10000 above & 13 & 43.33 & 20000-above & 12 & 40 \\
\hline Table & 30 & 100 & Total & 30 & 100 \\
\hline
\end{tabular}

Source: Field survey.

Age of the Firm: From the above table it shows that $23.33 \%$ of street vendors are doing business since from 1 year and $46.66 \%$ of were doing business by inception with $1-5$ year and $26.66 \%$ of respondents were doing business $5-10$ years and remaining $3.33 \%$ of respondents were doing business above 10 years.

Initial Investment: From the above table, it shows that $10 \%$ of street vendors' initial investment is between 10000-20000, and the remaining 40\% initial investment is above 20000 .

Monthly Income: From the above table it shows that $6.66 \%$ of street vendors' monthly income is below $5000,20 \%$ of the street vendors' monthly income between 10000-20000, and remaining $23.33 \%$ of the respondents' monthly income is above 20000.

Monthly Expenses: From the above table, it shows that $30 \%$ of the street vendors monthly expenses between $5000-7000$ and $26.66 \%$ of the

respondent's monthly expenses between 700010000 and the remaining $43.33 \%$ of the respondent's monthly expenses are above 10000.9 . Table showing which day in your business you have more customers.

Table 3: Business Season

\begin{tabular}{|l|c|c|}
\hline \multicolumn{1}{|c|}{ Day } & Frequency & Percentage \\
\hline Monday & 05 & 16.66 \\
\hline Tuesday & 01 & 03.33 \\
\hline Wednesday & 01 & 03.33 \\
\hline Thursday & - & - \\
\hline Friday & 05 & 16.66 \\
\hline Saturday & 09 & 30.00 \\
\hline Sunday & 09 & 30.00 \\
\hline \multicolumn{1}{|c|}{ Total } & 30 & 100 \\
\hline
\end{tabular}

Source: Field survey.

Day Season: From the above table it shows that $16.66 \%$ of respondents more in Monday 3.33\% of respondents are in Tuesday $3.33 \%$ of respondents 
are more in Wednesday $16.66 \%$ of respondents are Saturday and remaining 30\% of respondents more more in Friday and 30\% of respondents more in on Sunday.

Table 4: Family and Living Condition

\begin{tabular}{|c|c|c|c|c|c|}
\hline Type of family & $\mathbf{F q}$ & $\%$ & Living status & $\mathbf{F q}$ & $\%$ \\
\hline Joint & 04 & 13.33 & Yes & 29 & 96.66 \\
\hline Nuclear & 26 & 86.66 & No & 01 & 03.33 \\
\hline Total & 30 & 100 & Total & 30 & 100 \\
\hline Social status & $\mathbf{F q}$ & $\%$ & Family size & $\mathbf{F q}$ & $\%$ \\
\hline General merit & 06 & 20.00 & Up to- 3 & 15 & 50.00 \\
\hline $\mathrm{OBC}$ & 09 & 30.00 & $4-5$ & 09 & 30.00 \\
\hline $\mathrm{SC}$ & 05 & 16.66 & $6-7$ & 02 & 06.66 \\
\hline ST & 10 & 33.33 & 9 above & 04 & 13.33 \\
\hline Total & 30 & 100 & Total & 30 & 100 \\
\hline
\end{tabular}

Source: Field survey

Family Size: From the above table it shows that remaining $86.66 \%$ of respondents are in a nuclear $50 \%$ of respondents have come under 3 members family. In this, we can observe that nuclear families group. $30 \%$ of respondents have come under 5 are more in this category, and joint families are less. members group. And $6.66 \%$ of respondents have come under 7 Members of the group, and the remaining $13.33 \%$ of respondents come under the above 9 members group.

Social Status: From the above table, we can see that $20 \%$ of respondents have come under general merit. $30 \%$ of respondents have come under $\mathrm{OBC}$, and $16.66 \%$ of respondents have come under SC, and

Type Family: From the above table, it has the remaining $33.33 \%$ of people come under the ST $13.33 \%$ of respondents are in a joint family, and the category.

Table 5: Fact Sheet of Street vendors

\begin{tabular}{|c|c|c|c|c|c|}
\hline Seasonal variation & $\mathbf{F q}$ & $\%$ & Owning of cart & $\mathbf{F q}$ & $\%$ \\
\hline Yes & 28 & 93.33 & Yes & 11 & 36.66 \\
\hline No & 02 & 06.66 & No & 19 & 63.33 \\
\hline Total & 30 & 100 & Total & 30 & 100 \\
\hline Sources of finance & $\mathbf{F q}$ & $\%$ & Item varieties & $\mathbf{F q}$ & $\%$ \\
\hline Self finance & 11 & 36.66 & $1-2$ & 02 & 06.66 \\
\hline Relatives & 13 & 43.33 & $2-3$ & 16 & 53.33 \\
\hline Institutions & 06 & 20.00 & 5 \&above & 12 & 40.20 \\
\hline Total & 30 & 100 & Total & 30 & 100 \\
\hline Charges & $\mathbf{F q}$ & $\%$ & Other occupations & $\mathbf{F q}$ & $\%$ \\
\hline Yes & 20 & 66.66 & Yes & 8 & 26.66 \\
\hline No & 10 & 33.33 & No & 22 & 73.33 \\
\hline Total & 30 & 100 & Total & 30 & 100 \\
\hline Problems & $\mathbf{F q}$ & $\%$ & Mode of Savings & $\mathbf{F q}$ & $\%$ \\
\hline Place related & 08 & 26.66 & FD & 08 & 26.66 \\
\hline Bribe & 05 & 16.66 & $\mathrm{RD}$ & 01 & 03.33 \\
\hline Finance & 12 & 40.00 & LIC & 10 & 33.33 \\
\hline Labour & 06 & 20.00 & Chit fund & 11 & 36.66 \\
\hline Other issue & - & - & Other specify & - & - \\
\hline Total & 30 & 100 & Total & 30 & 100 \\
\hline
\end{tabular}




\begin{tabular}{|l|c|c|l|c|c|}
\hline \multicolumn{1}{|c|}{ Mode of receipt } & $\mathbf{F q}$ & $\mathbf{\%}$ & \multicolumn{1}{|c|}{ Savings } & $\mathbf{F q}$ & $\mathbf{\%}$ \\
\hline Google pay & 08 & 26.66 & Below 500 & 07 & 23.33 \\
\hline Phone pay & 09 & 30.00 & $500-1000$ & 06 & 20.00 \\
\hline Paytm & 13 & 43.33 & $1000-1500$ & 08 & 26.66 \\
\hline Other specify & - & - & $1500-2000$ & 09 & 30.00 \\
\hline \multicolumn{1}{|c|}{ Total } & $\mathbf{3 0}$ & $\mathbf{1 0 0}$ & Total & $\mathbf{3 0}$ & $\mathbf{1 0 0}$ \\
\hline
\end{tabular}

Source: Field survey.

Seasonal imbalance From the above table shows that $93.33 \%$ of respondents are saying Yes because they are facing seasonal imbalance in their business like rainy, summer season, and remaining $6.66 \%$ of respondents are saying No.

Source of Finance: From the above table it shows that $36.66 \%$ of respondents source is selffinance, $43.33 \%$ of respondents source is loans from the relatives, and the remaining $20 \%$ respondent source is loans from financial institutions.

Own Food Cart: From the above table, it shows $36.66 \%$ of respondents having their food truck, and the remaining $63.33 \%$ of respondents do not have food trucks. They take a rental basis.

Charges: From the above table shows that $66.66 \%$ of respondents are paid some fees for their workplace, and the remaining $33.33 \%$ of respondents are not paid any fees they freely serve food to customers.

Varieties of Items: From the above table it shows that $53.33 \%$ of the respondents will prepare 3-4 items, $40 \%$ of the respondents will 3-4 items prepare, and the remaining $6.66 \%$ of the people will prepare 1-2 items.

Table 6: Competition and Reason for Choosing the Business

\begin{tabular}{|l|c|c|l|c|c|}
\hline \multicolumn{1}{|c|}{ Uniqueness } & $\mathbf{F q}$ & $\mathbf{\%}$ & \multicolumn{1}{c|}{ Reason } & $\mathbf{F q}$ & $\mathbf{\%}$ \\
\hline By keeping good quality of items & 17 & 56.66 & Unemployment & 10 & 33.33 \\
\hline By reducing price & 04 & 13.33 & Self interest & 13 & 43.33 \\
\hline By providing home delivery & 03 & 10.00 & Low of education & 02 & 06.66 \\
\hline By providing hygienic & 06 & 20.00 & Family business & 06 & 20.00 \\
\hline \multicolumn{1}{|c|}{ Total } & $\mathbf{3 0}$ & $\mathbf{1 0 0}$ & Total & $\mathbf{3 0}$ & $\mathbf{1 0 0}$ \\
\hline
\end{tabular}

Competition: From the above table, $56.66 \%$ of the respondents are face competitors in business by keeping the good quality of items, $13.33 \%$ of the respondents are by providing home delivery services, and the remaining $20 \%$ of respondents are facing by providing a hygienic environment to them.

Reason for choosing this Business: From the above table $33.33 \%$ of the respondents are choosing this business because of unemployment, $43.33 \%$ of the respondents are choosing this business with selfinterest, $6.66 \%$ of the respondents are choosing this business because of low education \& remaining 20\% of the respondents are having a family business.

Living Conditions: From the above table $96.66 \%$ of the respondents are living conditions have changed by doing this business they earn some money to survive in future and remaining $3.33 \%$ of the respondents living condition was not changed they think to close their business because of loss.
Other Occupation: From the above table shows that $26 \%$ of the respondents are said Yes. Because some respondents make dual work like part-time jobs with others driving auto and tailoring etc. And the remaining $73.33 \%$ of the people said No because they are busy in their own business.

Problems: From the above table shows that $26.66 \%$ of the respondents are facing a someplace related issue, $16.66 \%$ of the people are giving bribe, $40 \%$ of the people are facing the finance-related issue, and remaining $20 \%$ of the people are facing the labor-related issue.

Mode of Payment: the above table it shows that $26.66 \%$ of the respondents are using Google pay, $30 \%$ of the respondents were using Phone pay, and the remaining $43.33 \%$ of respondents are using Pay tm.

Mode of Savings: From the above table, 26.66\% of the respondents are saving their money in FD, $3.33 \%$ of the respondents are save in $\mathrm{RD}, 33.33 \%$ of 
the respondents are saving their money in LIC and remaining $36.66 \%$ of the respondents are save in chit fund.

Savings: From the above table it shows that $23.33 \%$ of respondents are saving their money in below 500 rupees, $20 \%$ of respondents are saving $500-1000,26.66 \%$ of respondents are saving 1000 1500 , and remaining $30 \%$ respondents are saving 1500-2000.

\section{Findings}

- In gender-wise classification, $76.66 \%$ of respondents were male.

- Most of the respondents were in the age group between 30-40 years.

- Regarding marital status, it was found that $86.66 \%$ of respondents were married.

- $86.66 \%$ of the respondents were living in a nuclear family system.

- $20 \%$ of respondents have come under GM, and $30 \%$ of respondents come under the OBC category, and $16.66 \%$ of respondents come under SC, the remaining $33.33 \%$ of respondents come under the ST category.

- $93.33 \%$ of respondents were facing seasonal imbalance in their business like rainy, summer.

- $\quad 56.66 \%$ of respondents were face competitors in business by keeping the good quality of items.

- Most of the respondents belong to the middle class of the family.

- $40 \%$ of respondents were facing finance-related issues.

\section{Suggestions}

- The government has been introduced many schemes of the informal sector, especially for street food vending.

- Vendors should wear clean attire and head co.

- The government should give proper ID cards to street food vendors.

- The government should take some action again in their life.

- Promotional measures for making available credit, insurance, and other welfare schemes of social security for the street vendors.

- Street vendors not to be prevented by any person or police or any other authority from exercising their right to vend when carrying in the street vending following the terms and conditions of certificate of vending.

\section{Conclusion}

In this study indicated that food contamination in Davanagere City is mainly due to poor water hygienic during food preparation, The street food vendors having a small stall and mobile canteen to do their business, and street vendors having a stall to the overcrowded areas and bust public place. Street food vending business is providing to many unemployed members given employment opportunities. And it should be helping the urban area development; It is a plays a vital role in the urban area of many developing countries. Now a day's peoples are more going into the street food stall because of giving the food at low cost and good quality providing. The street food vendors are doing business for their livelihoods, family members, and households. Most of the street food vendors are poorly educated and untrained in the street food hygienic. Most of the street food vendors' foods are not well protected from flies. Like food storage, post-cooking food, it should because of the health problem of the customers and food poisoning of consumer health. The health problems in street foods like food safety, poor in water supply, some lock of infrastructure, uncleanness, and street food vendors do not have that much of the knowledge about the food safety measures. Street food vendors have should awareness of hazards; it should be because of health problems to the consumers. As per changes in the lifestyle of people, especially among urban dwellers, the demand for street food is also increased. To save time, especially the working people and students' majority are depending on street food, which is convenient and affordable.

\section{References}

Bajaj, P. et al. "Safety of Street Foods: Case Study of a Food Plaza in Delhi." Indian Food Industry, vol. 21, no. 3, 2002, pp. 39-43.

Bhowmik, S.K. "Street Vendors in Asia: A Review." Economic and Political Weekly, vol. 40, no. 22-23, 2005, pp. 2256-2264.

Chakravarthy, I and C. Canet. "Street Food in Calcutta." Food and Agricultural 
Organisation, 1996.

Gadi, Chirag, et al. "Study of Hygienic Practices of Street Food Vendors in Allahabad City and Determination of Critical Control Points for Safe Street Foods." 2018.

Gadaga, T.H. et al. "Socio-Economic and Hygienic Aspects of Street Food Vending in Maseru City, Lesotho." USWA Research Journal of Agriculture, Science and Technology, vol. 15, 2014, pp. 28-39.

Khairuzzaman, Md., et al. "Food Safety Challenges towards Safe, Healthy, and Nutritious Street Food in Bangladesh." International Journal of Food Science, 2014.

Kothari, C.R. and Gaurav Garg. Research Methodology: Methods \& Techniques, New Age International (P) Ltd, 2016.

Lin, Wai Yee and Yamao, Masahiro. "Consumer Attitude on Vendors Practices and Safety Aspects Street Foods in Yangon." GJETEMCP, vol. 1, no. 3, 2014, pp. 172-181. Mazumdar, M.D. and J.S. Goswami. "Impact of Training of Street Food Vendors on Food Safety and Hygiene Practices in the City of Guwahati." International Journal of Multidisciplinary Research Review, vol. 1, no. 3, 2016, pp. 37-40.

Mamun, M.A., et al. "Knowledge and Awareness of Children's Food Safety among School-based Street Food Vendors in Dhaka, Bangladesh." Foodborne Pathogens and Disease, vol. 10, no. 4, 2013, pp. 323-330.

Pappeswari, C. and Rajalakshmi, S. "SocioEconomic Conditions of Street Food Vendors - With Special Reference to Tiruchendur Area." Indian Journal of Commerce and Management Studies, vol. 5, no. 1, 2014, pp. 70-77.

Njaya, Tavonga. "Operations of Street Food Vendors and their Impact on Sustainable Urban Life in High Density Suburbs of Harare, in Zimbabwe." Asian Journal of Economic Modelling, vol. 2, no. 1, 2014, pp. 18-31.

Sezgin, Aybuke, and Nevin Sanlier. "Street Food Consumption in Terms of the Food Safety and Health." Journal of Human Sciences, vol. 13, no. 3, 2016, pp. 4072-4083.

\section{Author Details}

Harish Tigari, Assistant Professor and Co-ordinator, Davan PG Studies, Davangere, Karnataka, India.

Email ID: hstkplr148@gmail.com.

Ms. S. Shalini, Davan PG Studies, Davangere, Karnataka, India, Email ID: shalinishaluss303@gmail.com 